\title{
Encapsulation of Food Compounds Using Supercritical Technologies: Applications of Supercritical Carbon Dioxide as an Antisolvent
}

\author{
Eric Keven Silva, M. Angela A. Meireles* \\ LASEFI/DEA (Department of Food Engineering), FEA (School of Food Engineering), UNICAMP (University of Campinas), Campinas, \\ Brazil
}

\begin{abstract}
The application of supercritical technologies as an alternative to conventional methods for encapsulating food compounds is an area of research that can lead to significant innovations in various segments of industrial food processing. The existing supercritical techniques are classified as follows according to the function of the supercritical fluid used in the process: solvent; antisolvent; cosolvent or solute; nebulization compound; extractor and antisolvent techniques. Supercritical carbon dioxide $\left(\mathrm{scCO}_{2}\right)$ is the substance most widely used for obtaining micro/nanoparticles due to its unique characteristics, and among the existing encapsulation supercritical techniques, those using $\mathrm{scCO}_{2}$ as the antisolvent are more likely to be successful because food compounds are generally less soluble or even insoluble in $\mathrm{scCO}_{2}$. In this context, this review presents and discusses the applications of supercritical processes using $\mathrm{scCO}_{2}$ as the antisolvent for the encapsulation of substances of interest to the food industry.
\end{abstract}

Keywords Supercritical Fluids, SAS, SEDS, Phase equilibria, Wall material

\section{Introduction}

Various foods and nutrients, such as antioxidants, vitamins, flavorings and colorings, are naturally unstable under normal conditions of temperature and relative humidity, which restricts their availability and their application in food processing.

Encapsulation technologies have recently been developed to create procedures and formulations for the stabilization, solubilization and release of active components of interest to the food industry, which have incorporated and been applied to various products, thus improving their stability and maintaining their viability $[28,20]$.

Among the numerous conventional encapsulation processes, those based on supercritical technologies have attracted the food industry due to the possibility of working with thermolabile products and the ability to conduct particle engineering, i.e., to obtain new natural powdered additives, such as flavorings, colorings and antioxidants, with controlled characteristics, such as their size and size distribution. In particular, there is great interest in the preparation and application of nanometer-sized materials because they can possess new properties of industrial

* Corresponding author:

maameireles@gmail.com (M. Angela A. Meireles)

Published online at http://journal.sapub.org/fph

Copyright (C) 2014 Scientific \& Academic Publishing. All Rights Reserved value $[2,60,44]$.

Supercritical carbon dioxide $\left(\mathrm{scCO}_{2}\right)$ is the supercritical fluid that is most widely used in precipitation and encapsulation processes due to its favorable characteristics, such as its low toxicity, low cost, easy removal and non-flammability, and among the existing supercritical encapsulation techniques, those using $\mathrm{scCO}_{2}$ as an antisolvent are more likely to be successful in industrial applications because food compounds are generally poorly soluble or even insoluble in $\mathrm{scCO}_{2}[9,47,60]$.

The use of $\mathrm{scCO}_{2}$ as the antisolvent has been explored for different materials, such as polymers, pharmaceuticals, dyestuffs, explosives, inorganic compounds and catalysts. This review presents and discusses the application of supercritical processes using $\mathrm{scCO}_{2}$ as the antisolvent for the encapsulation of substances of interest to the food industry.

\section{Encapsulation}

Encapsulation is a physical coating process in which a substance (small solid particles, liquid droplets or a gas) which is called the active or core material, is surrounded by a material called the encapsulating agent or wall material, the function of which is to completely or partially isolate the active material in the form of capsules [25]. The goals of encapsulation are stabilizing the encapsulated materials, controlling its oxidative reactions, controlling its release, 
masking its taste, color and/or odor, prolonging its lifetime, reducing its volatility and reactivity and protecting the components against nutritional losses, as well as increasing its stability under adverse environmental conditions, such as the presence of light, oxygen and $\mathrm{pH}$ extremes $[14,1,25,10$, 11].

The obtained particles may have different morphologies and structures, such as that of a simple roofing membrane, a spherical or irregular morphology, a multiwalled structure or numerous cores in the same structure (Figure 1) [15]. The structures and morphologies of the particles are dependent on the materials (active and encapsulant) and the technique used in their preparation.

Several techniques have been developed for encapsulating active substances, such as spray-drying, spray-chilling, freeze-drying, coacervation, fluidized bedding, gelification, emulsion polymerization, extrusion and supercritical fluid processes, among others, and choosing the proper technique depends on the expected particle size, the biocompatibility and biodegradability of the particles, the physicochemical properties of the core and the encapsulant, the applications of the particles, the proposed mechanism for the release of the active material and the processing costs $[40,50]$.

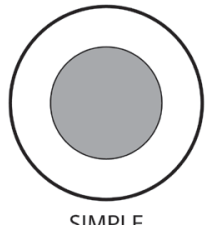

SIMPLE

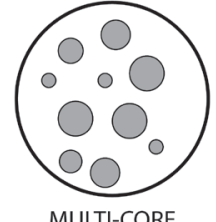

MULTI-CORE

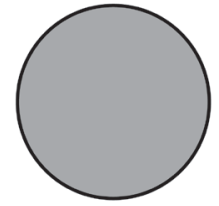

MATRIX

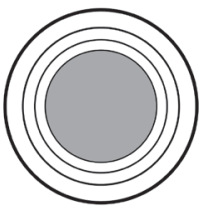

MULTI-WALL

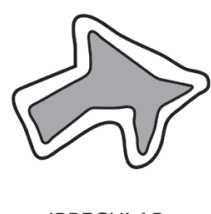

IRREGULAR

Figure 1. Morphologies of particles obtained using encapsulation processes (adapted from Gibbs et al. [15])

\section{Supercritical Fluids}

The advantages of using supercritical fluids (SCFs) rather than other solvents are primarily due to their physical and chemical properties being intermediate between those of liquids and gases and being easily adjustable with changes in temperature and pressure. SCFs have densities similar to those of liquids, viscosities near those of gases and diffusion coefficients greater than those of liquids, in addition to having a surface tension that is nearly zero [5].

Due to these transport properties, SCFs are applied for different purposes, such for extracting bioactive compounds, chromatographic analyses and particle formation [57, 47]. The mixing properties of liquid-gas are particularly useful in many applications related to nanotechnologies [44].

\section{1. $\mathrm{scCO}_{2}$ in the Particle Formation Process}

$\mathrm{scCO}_{2}$ is the SCF that is most widely used in precipitation processes because its critical properties, due to its $T_{c}$ of $304.2 \mathrm{~K}$ and its $P_{c}$ of $7.38 \mathrm{MPa}$, are relatively easily achieved (Figure 2) [53, 2]. These characteristics make $\mathrm{scCO}_{2}$ an attractive alternative material for a variety of applications, particularly for the processing of labile compounds.

$\mathrm{scCO}_{2}$ has other significant advantages, such as being available and therefore of low-cost. It exhibits moderate solubility in organic solvents and is nonflammable, nontoxic and environmentally safe, with the potential for use in developing new environmentally friendly processes. An important advantage of $\mathrm{scCO}_{2}$ is that it leaves no residue in the treatment medium, i.e., it is easily removed [5, 57]. Moreover, as for all SCFs, the rates of mass transfer in $\mathrm{scCO}_{2}$ are considerably higher than those in liquid solvents, and $\mathrm{scCO}_{2}$ can easily penetrate highly porous nanostructures $[47,2]$.

The solvent power of a supercritical fluid is a function of its density, which increases with increasing pressure at a constant temperature [5]. Nonpolar compounds are generally highly soluble in $\mathrm{scCO}_{2}$ because it is a nonpolar solvent. However, polar molecules can also be dissolved in $\mathrm{scCO}_{2}$. The solvating power of $\mathrm{scCO}_{2}$ can be increased by adding modifiers or co-solvents, such as ethanol, methanol and hexane [42].

$\mathrm{scCO}_{2}$ is completely miscible in water and in $\mathrm{H}_{2}, \mathrm{O}_{2}$ or $\mathrm{CO}$ at temperatures above $304.1 \mathrm{~K}$, whereas these gases are only slightly soluble in organic solvents. Higher concentrations of gases can be achieved in $\mathrm{scCO}_{2}$ than in other SCFs, which may be advantageous in producing nanostructured materials. For example, in reactive processes involving these gases, having them at high concentrations in the fluid phase may increase the reaction rates and overcome the limitations of the mass transfer rate across the gas-liquid interface [47].

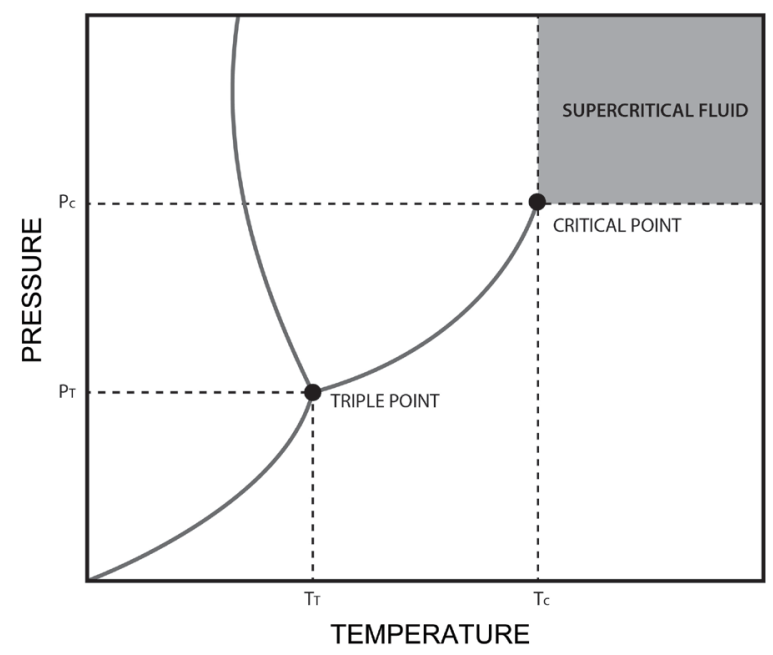

Figure 2. Pressure-temperature phase diagram for pure substances 
The abovementioned properties of $\mathrm{scCO}_{2}$ make it attractive for the processing and production of particles with controlled properties. The properties can be controlled by adjusting the kinetic and thermodynamic parameters of the system through adding surfactants or applying a specific configuration of the production process $[57,53,9,47,30]$.

\section{Supercritical Encapsulation Process}

The selection of the supercritical process for encapsulating active compounds must be initially based on the solubility of the substrate and the polymer matrix in the supercritical fluid, which is one of the limiting factors of supercritical techniques. The size, shape and structure of the desired particles, the production scale and the processing costs must also be considered [22, 2].

The techniques are classified according to the function of the supercritical fluid in the process, as follows: solvent; antisolvent; cosolvent or solute; nebulization compound; extractor and antisolvent techniques. $\mathrm{scCO}_{2}$ is the substance most often used to obtain pure or composite micro/nanoparticles due its unique characteristics. Table 1 presents the supercritical precipitation processes.

\subsection{Solvent Techniques}

The supercritical encapsulation techniques that are based on the solubilization of active compounds and wall materials in supercritical fluids are relatively simple. In the Rapid Expansion of a Supercritical Solution (RESS) process, the solutes are dissolved in $\mathrm{scCO}_{2}$ and then the homogeneous mixture is rapidly expanded in a container at atmospheric pressure using a suitable nozzle. With the sudden change in pressure, $\mathrm{scCO}_{2}$ loses its solvent power and the dissolved material precipitates [22].

To overcome the limitation of the RESS technique being suitable only for products of low polarity or moderate solubility in $\mathrm{scCO}_{2}$, patents that proposed changes to the process were developed, which included the following: adding a cosolvent to increase the solubility of the solute in $\mathrm{scCO}_{2}$, which is the Rapid Expansion of a Supercritical Solution with a Nonsolvent (RESS-N) process; applying a liquid solvent in the precipitation container to prevent the growth of particles during jet expansion and thus obtain smaller particles, which is the Rapid Expansion of a Supercritical Solution in a Liquid Solvent (RESOLV) process; and specifically using an aqueous solution containing a surfactant rather than a liquid solvent as a stabilizing agent, which is the Rapid Expansion of a Supercritical Solution in an Aqueous Solution (RESSAS) process (RESSAS) [57, 2, 47].

The application of the supercritical encapsulation process using $\mathrm{scCO}_{2}$ as a solvent is restricted in the area of food products because substances such as fats, vegetable oils and vitamins are only moderately soluble in $\mathrm{scCO}_{2}$ [60]. A few food compounds, such as rutin and a jabuticaba-skin extract rich in anthocyanins, have been encapsulated via RESS-N using polyethylene glycol (PEG) as the wall material and ethanol as a cosolvent $[51,48]$.

Table 1. Functions of $\mathrm{scCO}_{2}$ in the process of forming composed particles

\begin{tabular}{|c|c|c|c|}
\hline $\begin{array}{l}\mathrm{scCO}_{2} \\
\text { function }\end{array}$ & Process & Acronym & Reference \\
\hline \multirow[t]{4}{*}{ Solvent } & Rapid Expansion of Supercritical Solution & RESS & {$[22]$} \\
\hline & Rapid Expansion of Supercritical Solution into a Liquid Solvent & RESOLV & [57] \\
\hline & Rapid Expansion of Supercritical Solution into an Aqueous Solution & RESSAS & [47] \\
\hline & Rapid Expansion of Supercritical Solution with a Nonsolvent & RESS-N & {$[22]$} \\
\hline \multirow[t]{7}{*}{ Antisolvent } & Gas Antisolvent & GAS & [31] \\
\hline & Supercritical Antisolvent & SAS & [53] \\
\hline & Aerosol Solvent Extraction System & ASES & [2] \\
\hline & Particles by Compressed Antisolvent & PCA & [2] \\
\hline & Solution Enhanced Dispersion by Supercritical Fluids & SEDS & [22] \\
\hline & Supercritical Antisolvent Precipitation with Enhanced Mass Transfer & SAS-EM & {$[6]$} \\
\hline & Atomized Rapid Injection for Solvent Extraction & ARISE & [35] \\
\hline \multirow[t]{5}{*}{ Solute } & Particles from Gas-Saturated Solutions & PGSS & [22] \\
\hline & Particles from Gas-Saturated Solutions-Drying & PGSS-Drying & [36] \\
\hline & Gas-Assisted Melting Atomization & GAMA & [57] \\
\hline & Depressurization of an Expanded Liquid Organic Solution & DELOS & [53] \\
\hline & Pressure Reduction of Gas-Expanded Liquids & PPRGEL & [57] \\
\hline \multirow[t]{2}{*}{ Nebulization Compound } & Carbon Dioxide Assisted Nebulization with a Bubble Dryer & CAN-BD & [31] \\
\hline & Supercritical Fluid-Assisted Atomization & SAA & [47] \\
\hline Extractor and Antisolvent & Supercritical Fluid Extraction of Emulsions & SFEE & [9] \\
\hline
\end{tabular}




\subsection{Antisolvent Techniques}

The antisolvent gas (GAS) technique is a batch process in which the active substance and the wall material are solubilized in an organic solvent (primary solvent), characterizing an active solution (Figure 3 ). In this process, the solubilizing power of the encapsulant and the active compound in the primary solvent are reduced through the expansion of the active solution due to mixing it with a dense gas or supercritical fluid that is called the antisolvent [31].

The antisolvent saturates the active solution through the mass transfer process, which is rapid for $\mathrm{CO}_{2}$ due to its high diffusion rate, reducing the density of the mixture (active solution $+\mathrm{CO}_{2}$ ), increasing the volume of the solution and reducing its viscosity. The solvent power of a liquid is a function of its density, and thus the solubility of the solute (active compound + wall material) significantly decreases, reaching saturation and then supersaturation, at which point nucleation and the formation of fine particles occurs $[47,2$, $30]$.

The greatest advantage of the GAS technique is the ability to micronize and encapsulate polar components, i.e., components that are not soluble in $\mathrm{CO}_{2}$. However, because an organic solvent is used (primary solvent), traces quantities of the solvent can be detected in the particles obtained [3, 8].

Supercritical Antisolvent (SAS), Particles by Compressed Antisolvent (PCA), Aerosol Solvent Extraction System (ASES), Solution-Enhanced Dispersion by Supercritical Fluids (SEDS), Supercritical Antisolvent Precipitation with Enhanced Mass Transfer (SAS-EM) and Atomized Rapid Injection for Solvent Extraction (ARISE) processes were designed based on the GAS process, similarly to how other processes for supercritical encapsulation arose as the initial configurations were improved using the latest known methods through patent development [53]. These techniques differ mainly in that the active solution and the antisolvent come into contact [24]. These processes and their applications in food-compound encapsulation are presented in the following sections of this review.

\subsection{Cosolvent or Solute Techniques}

The Particles from Gas Saturated Solutions (PGSS) technique is particularly suitable for polymers and waxes because the dissolution of $\mathrm{CO}_{2}$ considerably reduces the melting point of these substances. The process does not require that the active substance or the polymer encapsulant be dissolved in the supercritical fluid. The method exploits the cooling phenomenon that occurs due to the Joule-Thompson effect during depressurization and the ability of $\mathrm{CO}_{2}$ to dissolve in organic compounds at high concentrations. The supercritical fluid is dissolved in a substrate, a substrate(s) solution in a solvent or a substrate(s) suspension in a solvent, followed by the rapid expansion of the saturated solution through a nozzle using a moderate pressure, which causes the formation of solid or liquid particles due to the intense cooling effect caused by the release of $\mathrm{CO}_{2}[22,9,2]$.

This process has long been used for micronization of foods and their derivatives, such as citric acid, chocolate, fatty acids and rosemary extracts [60], for menthol encapsulation in beeswax [26] and for the stabilization of the volatile compounds derived from several essential oils [33].

Among the variations of the PGSS process, the Particles from Gas Saturated Solutions-Drying (PGSS-Drying) technique is highlighted due to its application in encapsulating food compounds.

This technique relies on the use of $\mathrm{scCO}_{2}$ as a propellant solute and drying medium [36]. $\beta$-carotene was encapsulated in soy lecithin via PGSS-drying, yielding spherical particles $(10-500 \mu \mathrm{m})$ at an encapsulation efficiency of $60 \%$ [41].

\subsection{Compound-Nebulization Techniques}

In the Carbon Dioxide-Assisted Nebulization with a Bubble Dryer (CAN-BD) and Supercritical Fluid-Assisted Atomization (SAA) processes, $\mathrm{scCO}_{2}$ is used to promote the nebulization of the active solution. The main difference between the two techniques the limitation of the CAN-BD process to aqueous solutions, whereas SAA also works with organic solvent solutions. The mode of contact between the solution and $\mathrm{scCO}_{2}$ is another difference. In CAN-BD, contact is achieved using a simple T-mixer and a short residence time, and in the SAA process, a saturator is used $[57,31]$.

These techniques have been used to produce particles using a range of substances but particularly pharmaceutical compounds [60]. The CAN-BD technique was used to obtain particles of $\alpha$-lactose [55] and palmitic acid [54]. Particles of bovine serum albumin were obtained using the SAA technique [59].

\subsection{Extractor and Antisolvent Techniques}

Supercritical Fluid Extraction of Emulsions (SFEE) technique combines the efficiency of using a supercritical fluid as the antisolvent for the formation of particles with the effect of emulsification processes on the formation of nanoparticles [9]. The method is an extension of the SAS technique, in which $\mathrm{scCO}_{2}$ is used to extract the organic solvent from the droplets of oil-in-water $(\mathrm{o} / \mathrm{w})$ or water-in-oil (w/o) emulsions [34]. The ability to control the particle size is associated with the control of the size of the droplets in the dispersed phase in which the substance active is dissolved $[31,34]$. The main disadvantage of the process is that the final product generally consists of a suspension of the active component in water and not dry particles [17].

A shrimp-residue extract enriched with astaxanthin was encapsulated via the SFEE technique using the modified starch Hi-Cap 100 as the wall material and dichloromethane (DCM) as the primary solvent [37]. Lycopene and $\beta$-carotene solubilized in DCM were encapsulated using OSA modified starch as the encapsulant [49]. 


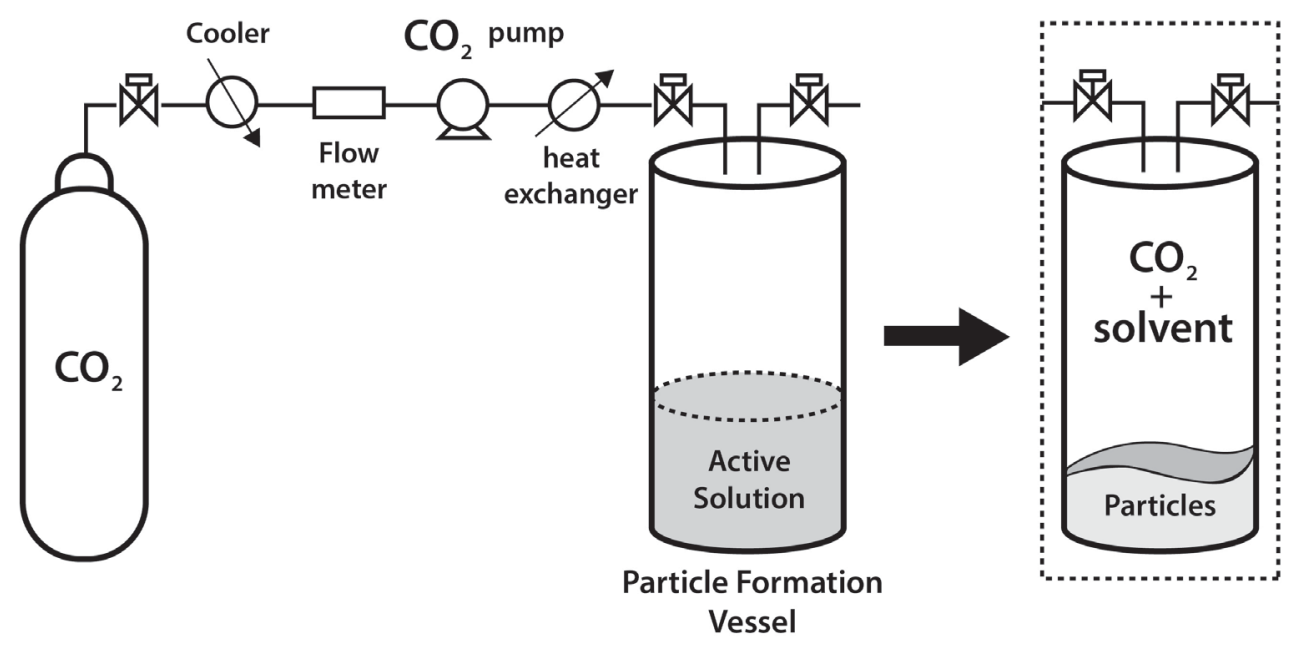

Figure 3. Simplified scheme of the GAS process

\section{SAS, PCA, ASES, SEDS, SAS-EM and ARISE Processes}

The SAS method is based on the same principle as the GAS process, but in a semi-continuous operation [44]. The processes also differ in that in the former, the active solution and the antisolvent fluid are continuously injected into the precipitation vessel through nozzles and their contact occurs with the vessel and with mixing so that supersaturation is achieved, leading to the formation of particles that accumulate within the container and are collected at the end of the operation [34]. According to Tabernero et al. [57], the SAS, PCA and ASES methods are similar processes. Figure 4 shows a simplified scheme of the SAS process.

The main advantages of the SAS process are associated with a reduced particle size due to supersaturation being caused by the rapid mixing of the supercritical fluid with the active solution [63]; the ability to prepare particles with high polymorphic purity, a higher solubility rate and an acceptable level of residual solvent [29]; the ability to control the size and size distribution of the obtained particles by varying the concentration of the active solution and other process parameters, including the temperature, pressure, feed rates of the solution and antisolvent and injector configuration [7]; the ability to encapsulate thermosensitive substances by choosing the appropriate antisolvent $[38,7]$; the feasibility of adapting the technique for continuous operation and, therefore, its favorability for large-scale production of encapsulated food compounds [63].

The main factor distinguishing the SEDS and SAS procedures is that in the SEDS technique, $\mathrm{scCO}_{2}$ is used not only as an antisolvent but also as a dispersing agent $[2,22]$. The SEDS process involves a specific configuration of the nozzle (Figure 5), which was developed to promote intense mixing of the supercritical fluid (antisolvent) and the active solution, with the aim of increasing the mass transfer rates and providing uniform conditions for crystallization, and thus the precipitation of particles with smaller sizes [57, 53]. Figure 5 shows the configuration of the nozzle used in the SEDS process as described in the patent of Hanna and York [18].

In addition to being used for its chemical properties, the antisolvent may also be used to enhance the mechanical effect of a nozzle designed for the coaxial passage of the feed fluids, which has a mixing chamber in its extremity that allows the simultaneous introduction and initial mixing of the antisolvent and the active solution. Mixing is terminated inside the particle-formation vessel. The high speed of the antisolvent spray breaks the solution into small droplets. Moreover, the processing conditions can be configured so that the supercritical fluid will extract the organic solvent from the solution while dispersing it $[22,2]$.

The technique in which an ultrasonic field is coupled to the SAS equipment to decrease the droplet size and improve mixing was called SAS-EM by Chattopadhyay and Gupta [6] The SAS-EM system consists of an ultrasonic precipitation vessel maintained at high pressure, which increases the rates of mass transfer and turbulence so that the droplet size is decreased, leading to the precipitation of particles smaller than those produced using the original method $[2,57]$. The contact between the active solution and the antisolvent is standardized based on the cross-flow properties [6].

Although adjustments to the nozzle configuration and the implementation of ultrasonic waves increase the control of the morphology of the particles, the SAS-EM process has some drawbacks, such as the need for operation at low flow rates to prevent clogging of the nozzle. The ARISE process was developed to overcome this limitation by eliminating the necessity of using a capillary injector [35]. 


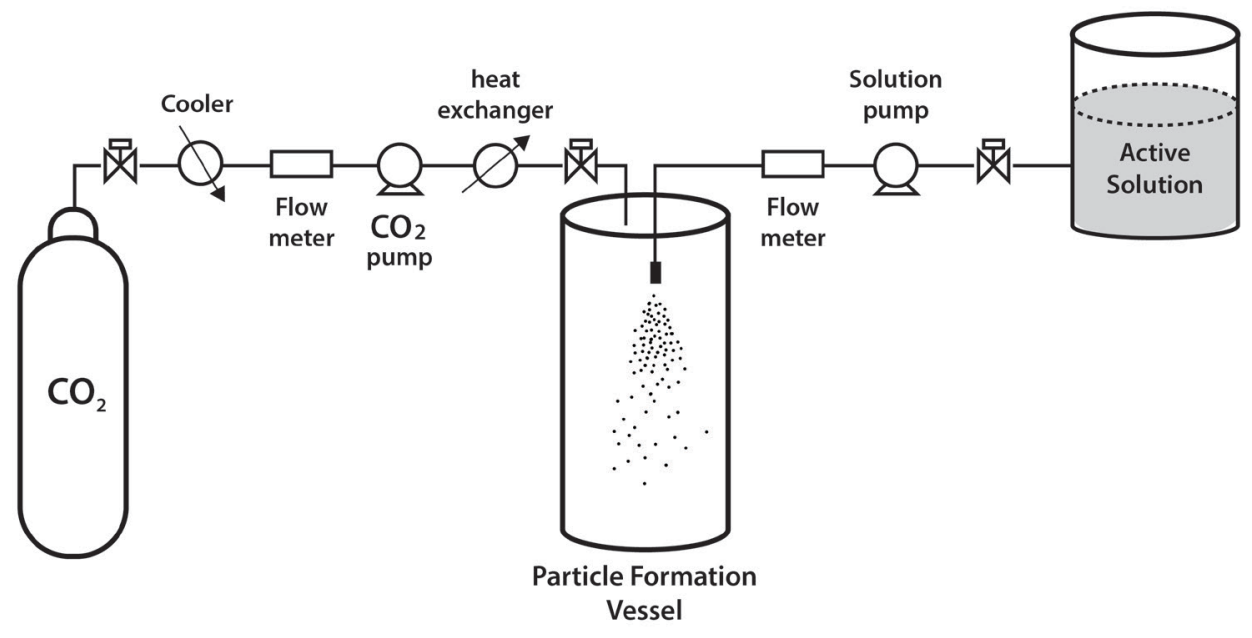

Figure 4. Simplified scheme of the SAS process

\section{Process Parameters and the Particle Size}

Process parameters, such as the pressure, temperature, rate of active solution flow, rate of antisolvent flow, the chemical and physical properties of the active compound, encapsulant and the organic solvent, intermolecular interactions between the $\mathrm{scCO}_{2}$-solvent and the $\mathrm{scCO}_{2}$-active compound/ encapsulant, concentration of the active substance and the encapsulant in the solution and the nozzle geometry directly affect the encapsulation characteristics, such as the relation among supersaturation, nucleation and particle growth, the particle size and distribution of sizes and the particle morphology in the processes that utilize a supercritical fluid as the antisolvent. Therefore, optimizing these parameters is fundamental for obtaining particles with controlled characteristics $[23,30,47,57,22,46]$. The size and size distribution of particles can also be adjusted changing the mode in which the antisolvent is added, in a batch or semi-continuous manner [47].

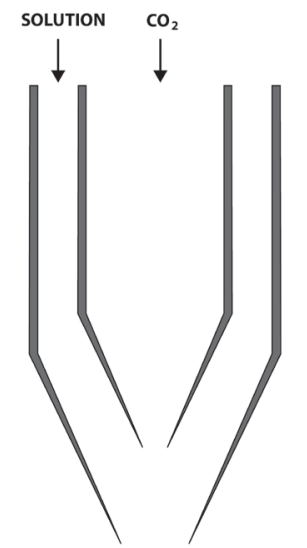

Figure 5. Coaxial nozzle used in the SEDS process

In their review of the application of the supercriticalantisolvent method in drug encapsulation, Kalani and Yunus
[23] discussed in detail the effect of each process parameter on the size of the particles obtained. However, the effects of the process variables are often contradictory and furthermore, there are no generally valid rules for the use of different types of active compounds, wall materials and organic solvents [45].

$\mathrm{Hu}$ et al. [19] studied the co-precipitation of lutein and zein solubilized in acetone and dimethyl sulfoxide $(7: 3, \mathrm{v} / \mathrm{v})$ using $\mathrm{scCO}_{2}$ as an antisolvent in a SEDS process. Process parameters, such as the temperature, pressure, lutein/zein ratio and the flow rate of the solution significantly affect the morphology (spherical) of the particles, the encapsulation efficiency $(34.44-83.15 \%)$ and the average particle size $(198-355 \mathrm{~nm})$.

\section{Organic Solvent}

The use of various organic solvents provides benefits, such as increasing the number of active compounds and the types of wall materials that can be processed in procedures that techniques use $\mathrm{scCO}_{2}$ as an antisolvent, although the application of toxic solvents, such as dichloromethane, dimethyl sulfoxide and others, is a factor that may limit their applications in the food-products encapsulation due to the presence of toxic residues in the final product [16]. According to Kalani and Yunus [23], the presence of residual toxic solvents in the obtained particles is the only drawback is associated with such processes.

Visentin et al. [58] encapsulated rosemary extracts with Pluronic ${ }^{\circledR}$ F 88 and Pluronic ${ }^{\circledR}$ F 127 via the SAS method and used ethanol, which is a food-grade solvent, as the primary solvent in the process.

\section{Encapsulant Material}

Selecting the appropriate wall material is an extremely important factor in the encapsulation of active compounds 
because the material must meet criteria such as having a particular mechanical strength, being compatible with the food product, protecting the core material from factors that could cause its deterioration, limiting the loss of volatile compounds, allowing controlled release, and having thermal properties compatible with the designated application of the product [14].

Cocero et al. [9] listed the biopolymers that are often used in supercritical encapsulation. Among the classes shown are polysaccharides and starch-based polymers, such as dextrin, cyclodextrin, modified starch and inulin. Although these materials are commonly used in processing various foods, there are no reports of their application in encapsulating food substances via a supercritical technique in which the $\mathrm{scCO}_{2}$ was used as the antisolvent.

\section{Phase Equilibria}

Most research on the encapsulation of food compounds using $\mathrm{scCO}_{2}$ as the antisolvent focused on the effects of the operating conditions (temperature, pressure, active solution and antisolvent flow rate, among others) on the size distribution and morphology of the particles. However, to assess the feasibility of the process and optimize the choice of the operating variables, it is important to understand the phase equilibrium of the systems because it plays a fundamental role in the mechanism of precipitation, nucleation, growth kinetics and mass transfer [52].

Importantly, studying the thermodynamic equilibria reached using these techniques is complex because they involve more than two substances (active compound, encapsulant, solvent and supercritical fluid) at different stages of aggregation, which may hamper determining the limits [60].

Franceschi et al. [13] studied the encapsulation of $\beta$-carotene using biocompatible poly (3-hydroxybutyrate-co -hydroxyvalerate) (PHBV) as the wall material and DCM as the primary solvent. They evaluated the phase equilibrium of the ternary systems $\mathrm{CO}_{2}+\mathrm{DCM}+\beta$-carotene and $\mathrm{CO}_{2}+$ $\mathrm{DCM}+\mathrm{PHBV}$. The experiments were performed at high pressure using a variable-volume cell that allowed visualization and were based on the static synthetic method. The temperature range investigated was $303 \mathrm{~K}-343 \mathrm{~K}$. The authors concluded that the adding solutes $(\beta$ - carotene and PHBV) to the binary system $\left(\mathrm{CO}_{2}+\mathrm{DCM}\right)$ had no significant effect on the transition pressures.

\section{Applications in Encapsulating Food Compounds}

The class of food compounds for which the largest number of studies of encapsulation via SAS processes is the carotenoids, such as lutein, which is found in some vegetables, such as spinach, cauliflower, peas, broccoli, and some fruits, such as oranges, papayas, peaches and kiwis, as well as in egg yolk [39, 32, 21, 61], bixin, the main pigment found in annatto seeds [51], $\beta$-carotene, an antioxidant pigment found in foods such as apricots, carrots, squash, beets, papayas, mangos and sweet potatoes [32], and astaxanthin, which is derived of the residues of shrimp processing [37].

Table 2. The application of the SAS and SEDS methods for encapsulating food compounds

\begin{tabular}{|c|c|c|c|c|c|c|}
\hline Process & $\begin{array}{c}\text { Core } \\
\text { material }\end{array}$ & Wall material & Solvent & Operating parameters & Results and observations & Reference \\
\hline SAS & $\begin{array}{l}\text { Polyphenols } \\
\text { (green tea } \\
\text { extract) }\end{array}$ & $\begin{array}{c}\text { Poly } \\
\text { (epsilon-caprolactone) }\end{array}$ & Acetone & $\begin{array}{l}\text { Pressure: } 8-12 \mathrm{MPa} \\
\text { Temperature: } 284-307 \mathrm{~K} \\
\mathrm{CO}_{2} \text { flow rate: } 5.56 \mathrm{E}-5-1.11 \mathrm{E}-4 \\
\mathrm{~kg} / \mathrm{s} \\
\text { Solution flow rate: } \\
3.95 \mathrm{E}-4 \text { - } 1.98 \mathrm{E}-3 \mathrm{~kg} / \mathrm{s} \\
\text { Polymer to solutes concentration } \\
\text { (w/w) ratio: } 4-58 \\
\text { Nozzle type: coaxial }\end{array}$ & $\begin{array}{l}\text { Scanning electron microscopy } \\
(\text { SEM) images of the products } \\
\text { showed small particles }(3-5 \mu \mathrm{m}) \\
\text { with a narrow size distribution } \\
\text { and a high degree of } \\
\text { agglomeration }\end{array}$ & [56] \\
\hline \multirow{2}{*}{ SAS } & Lutein & \multirow{2}{*}{ PEG } & \multirow{2}{*}{ DCM } & $\begin{array}{l}\text { Pressure: } 8 \text { - } 10 \mathrm{MPa} \\
\text { Temperature: } 288 \mathrm{~K} \\
\mathrm{CO}_{2} \text { flow rate: } 2.5 \text { and } 3.5 \mathrm{~kg} / \mathrm{h} \\
\text { Solution flow rate: } 1.7 \mathrm{~kg} / \mathrm{h} \\
\text { Lutein concentration: } 1-3 \mathrm{~g} / \mathrm{L} \\
\text { PEG concentration: } 12 \mathrm{~g} / \mathrm{L} \\
\text { Nozzle type: coaxial }\end{array}$ & $\begin{array}{l}\text { The products obtained were } \\
\text { spheres of PEG of approximately } \\
50 \mu \mathrm{m} \text { in diameter, in which } \\
\text { lutein was almost completely } \\
\text { covered }\end{array}$ & \multirow{2}{*}[32]{} \\
\hline & $\beta$-Carotene & & & $\begin{array}{l}\text { Pressure: } 8 \mathrm{MPa} \\
\text { Temperature: } 288 \mathrm{~K} \\
\mathrm{CO}_{2} \text { flow rate: } 2.5 \text { and } 3.5 \mathrm{~kg} / \mathrm{h} \\
\text { Solution flow rate: } 1.7 \mathrm{~kg} / \mathrm{h} \\
\beta \text {-Carotene concentration: } 1.2 \mathrm{~g} / \mathrm{L} \\
\text { PEG concentration: } 12 \text { and } 16 \mathrm{~g} / \mathrm{L} \\
\text { Nozzle type: coaxial }\end{array}$ & $\begin{array}{l}\text { Prismatic particles of } 100-200 \\
\mu \mathrm{m} \text { were produced. }\end{array}$ & \\
\hline
\end{tabular}




\begin{tabular}{|c|c|c|c|c|c|c|}
\hline SAS & $\begin{array}{l}\text { Bixin } \\
\text { (annatto seed } \\
\text { extract) }\end{array}$ & PEG & DCM & $\begin{array}{l}\text { Pressure: } 10 \mathrm{MPa} \\
\text { Temperature: } 313.15 \mathrm{~K} \\
\text { Solution flow rate: } 1 \mathrm{~mL} / \mathrm{min} \\
\mathrm{CO}_{2} \text { flow rate: } 0.6 \text { and } 1.5 \mathrm{~kg} / \mathrm{h} \\
\text { Mass ratio of bixin-rich } \\
\text { extract and PEG: } 1: 2 \text { and } 1: 10 \\
\text { Nozzle type: coaxial }\end{array}$ & $\begin{array}{l}\text { The higher } \mathrm{CO}_{2} \text { flow rate }(1.5 \\
\mathrm{kg} / \mathrm{h} \text { ) employed resulted in an } \\
\text { excessive loss of particles. The } \\
\text { particle size was } 33 \pm 2 \mu \mathrm{m}\end{array}$ & {$[51]$} \\
\hline SAS & $\begin{array}{l}\text { Rosemary } \\
\text { antioxidants }\end{array}$ & $\begin{array}{c}\text { Pluronic } ₫ \text { F } 88 \text { and } \\
\text { Pluronic } ₫ \text { F } 127\end{array}$ & Ethanol & $\begin{array}{l}\text { Pressure: } 8 \text { - } 10 \mathrm{MPa} \\
\text { Temperature: } 298-323 \mathrm{~K} \\
\text { Solution flow rate: } 1 \mathrm{~mL} / \mathrm{min} \\
\mathrm{CO}_{2} \text { flow rate: } 0.7 \mathrm{~kg} / \mathrm{h} \\
\text { Mass ratio between rosemary } \\
\text { extract and polymer: } 1: 2.5 \\
\text { Nozzle type: coaxial }\end{array}$ & $\begin{array}{l}\text { The size of the particles of } \\
\text { rosemary extracts encapsulated in } \\
\text { Pluronic were less than } 1 \mu \mathrm{m} \\
\text { based on SEM analysis }\end{array}$ & {$[58]$} \\
\hline SAS & $\begin{array}{l}\text { Astaxanthin } \\
\text { (Shrimp } \\
\text { extract) }\end{array}$ & Pluronic $₫$ F 127 & Acetone & $\begin{array}{l}\text { SMALL SCALE } \\
\text { Pressure: } 10-12 \mathrm{MPa} \\
\text { Temperature: } 308.15-318.15 \mathrm{~K} \\
\text { Solution flow rate: } 1-3 \mathrm{~mL} / \mathrm{min} \\
\mathrm{CO}_{2} \text { flow rate: } 1.0 \mathrm{~kg} / \mathrm{h} \\
\text { Extract concentration in the } \\
\text { solution: } 2-12 \mathrm{mg} / \mathrm{mL} \\
\text { Nozzle type: coaxial } \\
\text { LARGE SCALE } \\
\text { Pressure: } 10 \mathrm{MPa} \\
\text { Temperature: } 308.15 \text { and } 313.15 \mathrm{~K} \\
\text { Solution flow rate: } 4 \text { and } 5 \mathrm{~mL} / \mathrm{min} \\
\mathrm{CO}_{2} \text { flow rate: } 4.0 \text { and } 5.0 \mathrm{~kg} / \mathrm{h} \\
\text { Extract concentration in the } \\
\text { solution: } 6-12 \mathrm{mg} / \mathrm{mL} \\
\text { Nozzle type: coaxial }\end{array}$ & $\begin{array}{l}\text { The SEM results showed that the } \\
\text { SAS procedure was adequate for } \\
\text { producing microparticles (greater } \\
\text { than } 1 \mu \mathrm{m} \text { in diameter) for all } \\
\text { conditions evaluated. The highest } \\
\text { efficiency of astaxanthin } \\
\text { encapsulation }(74 \%) \text { in a } \\
\text { small-scale unit was obtained at } \\
10 \mathrm{MPa}, 308.15 \mathrm{~K} \text { and at a ratio } \\
\text { between the solution and the } \mathrm{CO}_{2} \\
\text { flow rate of } 1(\mathrm{~mL} / \mathrm{min}) /(\mathrm{kg} / \mathrm{h}) \text {. } \\
\text { Similar encapsulation efficiencies } \\
\text { were achieved using large-scale } \\
\text { SAS assays using the same } \\
\text { operational conditions used for } \\
\text { the small-scale unit }\end{array}$ & {$[37]$} \\
\hline SAS & Vitamin D3 & $\begin{array}{c}\text { Hydrogenated } \\
\text { phosphatidylcholine } \\
\text { (HPC) }\end{array}$ & $\begin{array}{c}\text { Ethanol and } \\
n \text {-hexane }\end{array}$ & $\begin{array}{l}\text { Pressure: } 8 \text { - } 12 \mathrm{MPa} \\
\text { Temperature: } 308-328 \mathrm{~K} \\
\text { Solution flow rate: } 0.5 \mathrm{~mL} / \mathrm{min} \\
\mathrm{CO}_{2} \text { flow rate: } 6.0 \mathrm{~kg} / \mathrm{h} \\
\mathrm{HPC} \text { concentration in the solution: } \\
40 \mathrm{mg} / \mathrm{mL} \\
\text { Vitamin } \mathrm{D}_{3} / \mathrm{HPC}: 5-15 \% \\
\text { Nozzle type: coaxial }\end{array}$ & $\begin{array}{l}\text { Nanoparticles of Vitamin } \mathrm{D}_{3} \text { in an } \\
\text { HPC matrix were formed. The } \\
\text { optimal conditions of preparation } \\
\text { were a temperature of } 318 \mathrm{~K} \text {, a } \\
\text { pressure of } 8 \mathrm{MPa} \text { and a mass } \\
\text { ratio of vitamin } \mathrm{D}_{3} \text { and } \mathrm{HPC} \text { of } \\
15 \% \text {. }\end{array}$ & {$[62]$} \\
\hline SAS & Quercetin & Pluronic $₫$ F 127 & Acetone & $\begin{array}{l}\text { Pressure: } 10 \mathrm{MPa} \\
\text { Temperature: } 313 \mathrm{~K} \\
\text { Solution flow rate: } 2 \mathrm{~mL} / \mathrm{min} \\
\mathrm{CO}_{2} \text { flow rate: } 2 \mathrm{~kg} / \mathrm{h} \\
\text { Solution concentration: } \\
0.005 \text { - } 0.02 \mathrm{~g} \text { of quercetin } / \mathrm{mL} \\
\text { acetone } \\
\text { Quercetin/carrier mass ratios: } \\
2: 1 \text { - } 1: 9 \\
\text { Nozzle type: coaxial }\end{array}$ & $\begin{array}{l}\text { Using a quercetin/polymer mass } \\
\text { ratio of } 1: 1 \text { yielded a highly } \\
\text { homogeneous product consisting } \\
\text { of spherical particles of } \\
\text { approximately } 1 \mu \mathrm{m} \text { in diameter }\end{array}$ & {$[12]$} \\
\hline SAS & Lutein & Poly-lactic acid (PLA) & Ethyl acetate & $\begin{array}{l}\text { Pressure: } 10 \mathrm{MPa} \\
\text { Temperature: } 290 \mathrm{~K} \\
\text { Solution flow rate: } 1000 \mathrm{~mL} / \mathrm{h} \\
\mathrm{CO}_{2} \text { flow rate: } 3.5 \mathrm{~kg} / \mathrm{h} \\
\text { Lutein concentration: } \\
350 \text { and } 700 \mathrm{ppm} \\
\text { PLA concentration: } 24000 \mathrm{ppm} \\
\text { Nozzle type: coaxial }\end{array}$ & $\begin{array}{l}\text { Spherical particles with diameters } \\
\text { between } \\
1 \mu \mathrm{m} \text { and } 5 \mu \mathrm{m} \text { were produced }\end{array}$ & [39] \\
\hline
\end{tabular}




\begin{tabular}{|c|c|c|c|c|c|c|}
\hline SAS & Lutein & $\begin{array}{l}\text { Hydroxypropylmethyl } \\
\text { cellulose phthalate } \\
\text { (HPMCP) }\end{array}$ & Acetone & $\begin{array}{l}\text { Pressure: } 11 \text { - } 15 \mathrm{MPa} \\
\text { Temperature: } 313-323 \mathrm{~K} \\
\text { Solution flow rate: } 1 \text { and } 2 \mathrm{~mL} / \mathrm{min} \\
\mathrm{CO}_{2} \text { flow rate: } 0.88-2.00 \mathrm{~kg} / \mathrm{h} \\
\text { Lutein concentration: } \\
0.1 \text { and } 0.8 \mathrm{mg} / \mathrm{mL} \\
\mathrm{HPMCP} \text { concentration: } \\
1-8 \mathrm{mg} / \mathrm{mL} \\
\text { Nozzle type: coaxial }\end{array}$ & $\begin{array}{l}\text { The optimal condition for the } \\
\text { highest lutein loading and } \\
\text { encapsulation efficiency is } 11 \\
\text { MPa, } 313 \mathrm{~K} \text { and the ratio of } \\
4.0: 0.8(\mathrm{mg} / \mathrm{mL}) \text { of } \\
\text { HPMCP:Lutein. The mean } \\
\text { diameter of the nanocapsules, } \\
\text { being nearly spherical, was in the } \\
\text { range of } 163-219 \mathrm{~nm}\end{array}$ & [21] \\
\hline SAS & Lutein & HPC & $\begin{array}{l}\text { DCM and } \\
\text { ethanol }\end{array}$ & $\begin{array}{l}\text { Pressure: } 8-16 \mathrm{MPa} \\
\text { Temperature: } 308-328 \mathrm{~K} \\
\text { Solution flow rate: } \\
0.5,1.0 \text { and } 1.5 \mathrm{~mL} / \mathrm{min} \\
\mathrm{CO}_{2} \text { flow rate: } 30 \mathrm{~mL} / \mathrm{min} \\
\text { Weight ratio of lutein/ } / \mathrm{HPC}: 10 \% \text {. } \\
\text { Lutein concentration: } 0.73 \mathrm{mg} / \mathrm{mL} \\
\text { Nozzle type: coaxial }\end{array}$ & $\begin{array}{l}\text { The optimal conditions for } \\
\text { preparing lutein/ HPC are a } \\
\text { temperature of } 308 \mathrm{~K} \text {, the } \\
\text { pressure of } 8 \mathrm{MPa} \text { and the } \\
\text { solution flow rate of } 1 \mathrm{~mL} / \mathrm{min} \text {, at } \\
\text { which the highest lutein loading } \\
\text { of } 55 \mathrm{mg} / \mathrm{g} \text { was obtained }\end{array}$ & [61] \\
\hline SEDS & Lutein & Zein & $\begin{array}{l}\text { Acetone and } \\
\text { dimethyl } \\
\text { sulfoxide }\end{array}$ & $\begin{array}{l}\text { Pressure: } 10-15 \mathrm{MPa} \\
\text { Temperature: } 305-318 \mathrm{~K} \\
\text { Solution flow rate: } 0.5-1.25 \\
\mathrm{~mL} / \mathrm{min} \\
\mathrm{CO}_{2} \text { flow rate: } 4 \mathrm{~kg} / \mathrm{h} \\
\text { Lutein } / \text { zein }(\mathrm{w} / \mathrm{w}): \\
1: 12,1: 24 \text { and } 1: 18\end{array}$ & $\begin{array}{l}\text { The lutein/zein nanoparticles in } \\
\text { narrow size range were obtained } \\
\text { at a pressure of } 10 \mathrm{MPa}, \mathrm{a} \\
\text { lutein/zein ratio of } 1: 18(\mathrm{w} / \mathrm{w}) \text { and } \\
\text { a solution flow rate of } 1.0 \mathrm{~mL} / \mathrm{min} \\
\text { at } 318 \mathrm{~K}\end{array}$ & [19] \\
\hline SEDS & $\beta$-Carotene & PHBV & DCM & $\begin{array}{l}\text { Pressure: } 8 \text { - } 12 \mathrm{MPa} \\
\text { Temperature: } 313 \mathrm{~K} \\
\text { Solution flow rate: } 1.0 \mathrm{~mL} / \mathrm{min} \\
\mathrm{CO}_{2} \text { flow rate: } 20-40 \mathrm{~mL} / \mathrm{min} \\
\beta \text {-carotene concentration: } \\
4-8 \mathrm{mg} / \mathrm{mL} \\
\text { PHBV concentration: } 10-40 \\
\mathrm{mg} / \mathrm{mL}\end{array}$ & $\begin{array}{l}\text { The co-precipitation tests } \\
\text { indicated that encapsulation of } \\
\beta \text {-carotene in PHBV at up to } 80 \% \\
\text { efficiency was achieved at a mass } \\
\text { ratio of } 1: 3 \text { ( } \beta \text {-carotene to } \\
\text { polymer) in the organic solution }\end{array}$ & [13] \\
\hline SEDS & $\beta$-Carotene & PHBV & DCM & $\begin{array}{l}\text { Pressure: } 8 \text { - } 20 \mathrm{MPa} \\
\text { Temperature: } 313 \mathrm{~K} \\
\text { Solution flow rate: } 1.0 \mathrm{~mL} / \mathrm{min} \\
\mathrm{CO}_{2} \text { flow rate: } 40 \mathrm{~mL} / \mathrm{min} \\
\beta \text {-Carotene concentration: } \\
4 \text { and } 8 \mathrm{mg} / \mathrm{mL} \\
\text { PHBV concentration: } 30 \mathrm{mg} / \mathrm{mL}\end{array}$ & $\begin{array}{l}\text { The encapsulation data showed } \\
\text { that increasing the concentration } \\
\text { of } \beta \text {-carotene while maintaining a } \\
\text { fixed PHBV content resulted in a } \\
\text { higher percentage of solute being } \\
\text { encapsulated, increasing the } \\
\text { encapsulation efficiency }\end{array}$ & [43] \\
\hline SEDS & $\begin{array}{c}\text { Grape seed } \\
\text { extract }\end{array}$ & PHBV & DCM & $\begin{array}{l}\text { Pressure: } 8 \text { - } 12 \mathrm{MPa} \\
\text { Temperature: } 308-318 \mathrm{~K} \\
\text { Solution flow rate: } 1.67 \times 10^{-8} \mathrm{~m}^{3} / \mathrm{s} \\
\mathrm{CO}_{2} \text { flow rate: } 3.33 \times 10^{-7} \mathrm{~m}^{3} / \mathrm{s} \\
\text { Grape seed extract to } \mathrm{PHBV} \text { mass } \\
\text { ratio: } \\
1: 1,1: 2 \text { and } 1: 3 \\
\text { Extract concentration: } 6.67-20.02 \\
\mathrm{~kg} / \mathrm{m}^{3} \\
\mathrm{PHBV} \text { concentration: } 20.00-20.03 \\
\mathrm{~kg} / \mathrm{m}^{3}\end{array}$ & $\begin{array}{l}\text { The temperature had the greatest } \\
\text { effect on particle morphology. } \\
\text { Lower temperatures led to less } \\
\text { agglomeration and smaller } \\
\text { particles. The best conditions } \\
\text { resulted spherical particles with } \\
\text { the smallest size, } 0.70 \mu \mathrm{m}, \\
\text { obtained at a pressure of } 8 \mathrm{MPa} \text {, a } \\
\text { temperature of } 308 \mathrm{~K} \text {, a } 1: 1 \mathrm{mass} \\
\text { ratio and concentration of the } \\
\text { extract and PHBV, both at } 20 \mathrm{~kg} \\
\mathrm{~m}^{-3} \text {, while maintaining all of the } \\
\text { other processing variables at the } \\
\text { fixed values }\end{array}$ & [4] \\
\hline SEDS & Astaxanthin & PHBV & DCM & $\begin{array}{l}\text { Pressure: } 8 \text { and } 10 \mathrm{MPa} \\
\text { Temperature: } 308 \mathrm{~K} \\
\text { Solution flow rate: } 1.0 \mathrm{~mL} / \mathrm{min} \\
\mathrm{CO}_{2} \text { flow rate: } 20 \mathrm{~mL} / \mathrm{min} \\
\text { Biomass containing astaxanthin: } \\
\text { dichloromethane } \\
\text { at } 5,8 \text { and } 10 \mathrm{mg} / \mathrm{mL} \\
\mathrm{PHBV} \text { concentration: } 20.00 \\
\mathrm{mg} / \mathrm{mL}\end{array}$ & $\begin{array}{l}\text { The precipitation pressure had the } \\
\text { strongest effect on the size of the } \\
\text { particles formed, and the smallest } \\
\text { mean particle size, } 0.128 \mu \mathrm{m} \text {, was } \\
\text { obtained using the highest } \\
\text { pressure tested, } 10 \mathrm{MPa} \text {. }\end{array}$ & [27] \\
\hline
\end{tabular}


Other studies of encapsulating food compounds have involved an extract of the fresh roots of green tea plants that is rich in polyphenols and catechins [56], rosemary extracts that are rich in antioxidants, such as butylated hydroxyanisole (BHA) and butylated hydroxytoluene (BHT) [58], cholecalciferol (vitamin D3) [62], and quercetin, a natural flavonoid that is found mainly in apples, grapes, onions and broccoli [12].

Boschetto et al. [4] encapsulated a grape-seed extract that is rich in unsaturated fatty acids and antioxidant compounds via the SEDS technique using biocompatible PHBV as the encapsulant, DCM as the primary solvent and $\mathrm{scCO}_{2}$ as the antisolvent. They obtained spherical particles with the small size of approximately $0.7 \mu \mathrm{m}$ at an encapsulation efficiency of $66.01 \%$.

Table 2 presents a summary of the investigations in which SAS and SEDS techniques were utilized for encapsulating compounds of interest to the food industry, as indicated by the authors of the respective studies. There are no records of studies that applied the SAS-EM or ARISE processes to food-compound encapsulation.

\section{Conclusions}

This review has shown that using $\mathrm{scCO}_{2}$ as the antisolvent is a viable technique for encapsulating compounds of interest to the food industry. To date, there are few reports in the literature regarding this technique, with approximately 15 such articles found in the journals that are indexed in the Web-of-Science and Scopus databases reporting the encapsulation of compounds such as carotenoids [39, 32, 13, 21, 51, 37, 61], antioxidants [58], flavonoids [12] and polyphenols [56].

The SAS and SEDS techniques were the only processes used in the reported studies. These processes are good alternatives encapsulating thermosensitive substances and are suitable for applications in which particle engineering is desired. In all of the studies that applied the SAS configuration, the pattern of contact between the supercritical fluid and the active solution was the same, with feeding conducted in the coaxial mode $[51,32,56,58,37,62$, $12,39,21,61]$. Due to the paucity of relevant studies, it was not possible to clearly establish the effect of the process parameters on encapsulation via the SAS and SEDS techniques.

In particular, further studies that use food-grade organic solvents that are generally recognized as safe (GRAS), such as ethanol, and wall materials that are derived from natural sources, such as modified starches, dextrins and inulin, may result in major innovations in the field of food engineering.

\section{ACKNOWLEDGEMENTS}

The authors are grateful to CNPq (470916/2012-5) and FAPESP (2012/10685-8) for their financial support. Eric
Keven Silva is grateful to CNPq (140275/2014-2) for a Ph.D. assistantship. M. Angela A. Meireles is grateful to CNPq for the productivity grant (301301/2010-7).

\section{REFERENCES}

[1] A. K. Anal, H. Singh, "Recent advances in microencapsulation of probiotics for industrial applications and targeted delivery", Trends in Food Science and Technology, vol.18, no.5, pp.240-251, 2007.

[2] M. Bahrami, S. Ranjbarian, "Production of micro- and nano-composite particles by supercritical carbon dioxide", Journal of Supercritical Fluids, vol.40, no.2, pp.263-283, 2007.

[3] Yousef Bakhbakhi, Paul A. Charpentier, Sohrab Rohani, "Experimental study of the GAS process for producing microparticles of beclomethasone-17,21-dipropionate suitable for pulmonary delivery", International Journal of Pharmaceutics, vol.309, no.1-2, pp.71-80, 2006.

[4] Daiane L. Boschetto, Irede Dalmolin, Alana M. de Cesaro, Aline A. Rigo, Sandra R. S. Ferreira, M. Angela A. Meireles, Eduardo A. C. Batista, J. Vladimir Oliveira, "Phase behavior and process parameters effect on grape seed extract encapsulation by SEDS technique", Industrial Crops and Products, vol.50, no.0, pp.352-360, 2013.

[5] G. Brunner, "Supercritical fluids: technology and application to food processing", Journal of Food Engineering, vol.67, no.1-2, pp.21-33, 2005.

[6] P. Chattopadhyay, R. B. Gupta, "Supercritical CO2 based production of magnetically responsive micro- and nanoparticles for drug targeting", Industrial and Engineering Chemistry Research, vol.41, no.24, pp.6049-6058, 2002.

[7] Ai-Zheng Chen, Yi Li, Foo-Tim Chau, Tsui-Yan Lau, Jun-Yan $\mathrm{Hu}$, Zheng Zhao, Daniel Kam-wah Mok, "Application of organic nonsolvent in the process of solution-enhanced dispersion by supercritical $\mathrm{CO} 2$ to prepare puerarin fine particles", The Journal of Supercritical Fluids, vol.49, no.3, pp.394-402, 2009.

[8] M. J. Cocero, S. Ferrero, "Crystallization of $\beta$-carotene by a GAS process in batch Effect of operating conditions", The Journal of Supercritical Fluids, vol.22, no.3, pp.237-245, 2002.

[9] M. J. Cocero, A. Martín, F. Mattea, S. Varona, "Encapsulation and co-precipitation processes with supercritical fluids: Fundamentals and applications", Journal of Supercritical Fluids, vol.47, no.3, pp.546-555, 2009.

[10] J. M. G. Costa, S. V. Borges, A. A. C. T. Hijo, E. K. Silva, G. R. Marques, M. Â Cirillo, V. M. De Azevedo, "Matrix structure selection in the microparticles of essential oil oregano produced by spray dryer", Journal of Microencapsulation, vol.30, no.8, pp.717-727, 2013.

[11] Regiane Victória de Barros Fernandes, Soraia Vilela Borges, Diego Alvarenga Botrel, Eric Keven Silva, Joyce Maria Gomes da Costa, Fabiana Queiroz, "Microencapsulation of Rosemary Essential Oil: Characterization of Particles", Drying Technology, vol.31, no.11, pp.1245-1254, 2013. 
[12] M. Fraile, R. Buratto, B. Gómez, A. Martín, M. J. Cocero, "Enhanced delivery of quercetin by encapsulation in poloxamers by supercritical antisolvent process", Industrial and Engineering Chemistry Research, vol.53, no.11, pp.4318-4327, 2014.

[13] Elton Franceschi, Alana M. De Cesaro, Mirian Feiten, Sandra R. S. Ferreira, Cláudio Dariva, Marcos H. Kunita, Adley F. Rubira, Edvani C. Muniz, Marcos L. Corazza, J. Vladimir Oliveira, "Precipitation of $\beta$-carotene and PHBV and co-precipitation from SEDS technique using supercritical CO2", The Journal of Supercritical Fluids, vol.47, no.2, pp.259-269, 2008.

[14] A. Gharsallaoui, G. Roudaut, O. Chambin, A. Voilley, R. Saurel, "Applications of spray-drying in microencapsulation of food ingredients: An overview", Food Research International, vol.40, no.9, pp.1107-1121, 2007.

[15] B. F. Gibbs, S. Kermasha, I. Alli, C. N. Mulligan, "Encapsulation in the food industry: A review", International Journal of Food Sciences and Nutrition, vol.50, no.3, pp.213-224, 1999.

[16] P. J. Ginty, M. J. Whitaker, K. M. Shakesheff, S. M. Howdle, "Drug delivery goes supercritical", Materials Today, vol.8, no.8, Supplement, pp.42-48, 2005.

[17] M. T. M. S. Gomes, D. T. Santos, M. A. A. Meireles, "Trends in particle formation of bioactive compounds using supercritical fluids and nanoemulsions ", Food and Public Health, vol.2, no.5, pp.142-152, 2012.

[18] M. Hanna, P. York, WO Patent 95/012211994.

[19] Daode Hu, Changchun Lin, Liang Liu, Sining Li, Yaping Zhao, "Preparation, characterization, and in vitro release investigation of lutein/zein nanoparticles via solution enhanced dispersion by supercritical fluids", Journal of Food Engineering, vol.109, no.3, pp.545-552, 2012.

[20] S. M. Jafari, E. Assadpoor, Y. He, B. Bhandari, "Encapsulation efficiency of food flavours and oils during spray drying", Drying Technology, vol.26, no.7, pp.816-835, 2008.

[21] Heyang Jin, Fei Xia, Cuilan Jiang, Yaping Zhao, Lin He, "Nanoencapsulation of Lutein with Hydroxypropylmethyl Cellulose Phthalate by Supercritical Antisolvent", Chinese Journal of Chemical Engineering, vol.17, no.4, pp.672-677, 2009.

[22] J. Jung, M. Perrut, "Particle design using supercritical fluids: Literature and patent survey", Journal of Supercritical Fluids, vol.20, no.3, pp.179-219, 2001.

[23] M. Kalani, R. Yunus, "Application of supercritical antisolvent method in drug encapsulation: a review", International Journal of Nanomedicine, vol.6, no.pp.1429-1442, 2011.

[24] Zeljko Knez, Eckhard Weidner, "Particles formation and particle design using supercritical fluids", Current Opinion in Solid State and Materials Science, vol.7, no.4-5, pp.353-361, 2003

[25] W. Krasaekoopt, B. Bhandari, H. Deeth, "Evaluation of encapsulation techniques of probiotics for yoghurt", International Dairy Journal, vol.13, no.1, pp.3-13, 2003.

[26] H. Lan, L. Zhu, B. He, W. Hong, J. Li, "Encapsulation of menthol in beeswax by a supercritical fluid technique", International Journal of Chemical Engineering, vol.2010.

[27] Francisco R. S. Machado Jr, Daiane F. Reis, Daiane L. Boschetto, Janaína F. M. Burkert, Sandra R. S. Ferreira, J. Vladimir Oliveira, Carlos André V. Burkert, "Encapsulation of astaxanthin from Haematococcus pluvialis in PHBV by means of SEDS technique using supercritical CO2", Industrial Crops and Products, vol.54, no.0, pp.17-21, 2014.

[28] A. Madene, M. Jacquot, J. Scher, S. Desobry, "Flavour encapsulation and controlled release - A review", International Journal of Food Science and Technology, vol.41, no.1, pp.1-21, 2006

[29] Viktor Majerik, Gérard Charbit, Elisabeth Badens, Géza Horváth, László Szokonya, Nathalie Bosc, Eric Teillaud, "Bioavailability enhancement of an active substance by supercritical antisolvent precipitation", The Journal of Supercritical Fluids, vol.40, no.1, pp.101-110, 2007.

[30] A. Martín, M. J. Cocero, "Micronization processes with supercritical fluids: Fundamentals and mechanisms", Advanced Drug Delivery Reviews, vol.60, no.3, pp.339-350, 2008.

[31] A. Martín, M. J. Cocero, "Precipitation processes with supercritical fluids: Patents review", Recent Patents on Engineering, vol.2, no.1, pp.9-20, 2008.

[32] A. Martín, F. Mattea, L. Gutiérrez, F. Miguel, M. J. Cocero, "Co-precipitation of carotenoids and bio-polymers with the supercritical anti-solvent process", The Journal of Supercritical Fluids, vol.41, no.1, pp.138-147, 2007.

[33] A. Martín, S. Varona, A. Navarrete, M. J. Cocero, "Encapsulation and co-precipitation processes with supercritical fluids: Applications with essential oils", Open Chemical Engineering Journal, vol.4, no.1, pp.31-41, 2010.

[34] F. Mattea, A. Martín, M. J. Cocero, "Carotenoid processing with supercritical fluids", Journal of Food Engineering, vol.93, no.3, pp.255-265, 2009.

[35] S. A. B. V. Melo, L. T. Danh, R. Mammucari, N. R. Foster, "Dense $\mathrm{CO} 2$ antisolvent precipitation of levothyroxine sodium: A comparative study of GAS and ARISE techniques based on morphology and particle size distributions", The Journal of Supercritical Fluids. DOI: 10.1016/j.supflu.2013.11.019

[36] D. Meterc, M. Petermann, E. Weidner, "Drying of aqueous green tea extracts using a supercritical fluid spray process", The Journal of Supercritical Fluids, vol.45, no.2, pp.253-259, 2008.

[37] N. Mezzomo, E. de Paz, M. Maraschin, A. Martin, M. J. Cocero, S. R. S. Ferreira, "Supercritical anti-solvent precipitation of carotenoid fraction from pink shrimp residue: Effect of operational conditions on encapsulation efficiency", Journal of Supercritical Fluids, vol.66, no.pp.342-349, 2012.

[38] F. Miguel, A. Martín, T. Gamse, M. J. Cocero, "Supercritical anti solvent precipitation of lycopene: Effect of the operating parameters", The Journal of Supercritical Fluids, vol.36, no.3, pp.225-235, 2006.

[39] F. Miguel, A. Martín, F. Mattea, M. J. Cocero, "Precipitation of lutein and co-precipitation of lutein and poly-lactic acid with the supercritical anti-solvent process", Chemical Engineering and Processing: Process Intensification, vol.47, 
no.9-10, pp.1594-1602, 2008.

[40] Alla Nesterenko, Isabelle Alric, Françoise Silvestre, Vanessa Durrieu, "Vegetable proteins in microencapsulation: A review of recent interventions and their effectiveness", Industrial Crops and Products, vol.42, no.0, pp.469-479, 2013.

[41] E. Paz, Á Martín, M. J. Cocero, "Formulation of $\beta$-carotene with soybean lecithin by PGSS (Particles from Gas Saturated Solutions)-drying", Journal of Supercritical Fluids, vol.72, no.pp.125-133, 2012.

[42] C. G. Pereira, M. A. A. Meireles, "Supercritical fluid extraction of bioactive compounds: Fundamentals, applications and economic perspectives", Food and Bioprocess Technology, vol.3, no.3, pp.340-372, 2010.

[43] Wagner Luiz Priamo, Alana M. de Cezaro, Sandra R. S. Ferreira, J. Vladimir Oliveira, "Precipitation and encapsulation of $\beta$-carotene in PHBV using carbon dioxide as anti-solvent", The Journal of Supercritical Fluids, vol.54, no.1, pp.103-109, 2010.

[44] E. Reverchon, R. Adami, "Nanomaterials and supercritical fluids", The Journal of Supercritical Fluids, vol.37, no.1, pp.1-22, 2006.

[45] E. Reverchon, G. Della Porta, M. G. Falivene, "Process parameters and morphology in amoxicillin micro and submicro particles generation by supercritical antisolvent precipitation", The Journal of Supercritical Fluids, vol.17, no.3, pp.239-248, 2000.

[46] Ernesto Reverchon, "Supercritical antisolvent precipitation of micro- and nano-particles", The Journal of Supercritical Fluids, vol.15, no.1, pp.1-21, 1999.

[47] D. Sanli, S. E. Bozbag, C. Erkey, "Synthesis of nanostructured materials using supercritical CO 2: Part I. Physical transformations", Journal of Materials Science, vol.47, no.7, pp.2995-3025, 2012.

[48] D. T. Santos, J. Q. Albarelli, M. M. Beppu, M. A. A. Meireles, "Stabilization of anthocyanin extract from jabuticaba skins by encapsulation using supercritical $\mathrm{CO} 2$ as solvent", Food Research International, vol.50, no.2, pp.617-624, 2013.

[49] D. T. Santos, A. Martín, M. A. A. Meireles, M. J. Cocero, "Production of stabilized sub-micrometric particles of carotenoids using supercritical fluid extraction of emulsions", The Journal of Supercritical Fluids, vol.61, no.0, pp.167-174, 2012.

[50] D. T. Santos, M. A. A. Meireles, "Carotenoid pigments encapsulation: Fundamentals, techniques and recent trends", Open Chemical Engineering Journal, vol.4, no.1, pp.42-50, 2010.

[51] D. T. Santos, M. A. A. Meireles, "Micronization and encapsulation of functional pigments using supercritical carbon dioxide", Journal of Food Process Engineering, vol.36, no.1, pp.36-49, 2013.
[52] A. Shariati, C. J. Peters, "Measurements and modeling of the phase behavior of ternary systems of interest for the GAS process: I. The system carbon dioxide+1-propanol+salicylic acid", The Journal of Supercritical Fluids, vol.23, no.3, pp.195-208, 2002.

[53] A. Shariati, C. J. Peters, "Recent developments in particle design using supercritical fluids", Current Opinion in Solid State and Materials Science, vol.7, no.4-5, pp.371-383, 2003.

[54] R. E. Sievers, E. T. S. Huang, J. A. Villa, G. Engling, P. R. Brauer, "Micronization of water-soluble or alcohol-soluble pharmaceuticals and model compounds with a low-temperature Bubble Dryer ${ }^{\circledR} "$, The Journal of Supercritical Fluids, vol.26, no.1, pp.9-16, 2003.

[55] R. E. Sievers, P. D. Milewski, S. P. Sellers, B. A. Miles, B. J. Korte, K. D. Kusek, G. S. Clark, B. Mioskowski, J. A. Villa, "Supercritical and near-critical carbon dioxide assisted low-temperature bubble drying", Industrial and Engineering Chemistry Research, vol.39, no.12, pp.4831-4836, 2000.

[56] M. V. Sosa, S. Rodríguez-Rojo, F. Mattea, M. Cismondi, M. J. Cocero, "Green tea encapsulation by means of high pressure antisolvent coprecipitation", The Journal of Supercritical Fluids, vol.56, no.3, pp.304-311, 2011.

[57] A. Tabernero, E. M. Martín del Valle, M. A. Galán, "Supercritical fluids for pharmaceutical particle engineering: Methods, basic fundamentals and modelling", Chemical Engineering and Processing: Process Intensification, vol.60, no.pp.9-25, 2012.

[58] A. Visentin, S. Rodríguez-Rojo, A. Navarrete, D. Maestri, M. J. Cocero, "Precipitation and encapsulation of rosemary antioxidants by supercritical antisolvent process", Journal of Food Engineering, vol.109, no.1, pp.9-15, 2012.

[59] Qi Wang, Yi-Xin Guan, Shan-Jing Yao, Zi-Qiang Zhu, "Controllable preparation and formation mechanism of BSA microparticles using supercritical assisted atomization with an enhanced mixer", The Journal of Supercritical Fluids, vol.56, no.1, pp.97-104, 2011.

[60] E. Weidner, "High pressure micronization for food applications", Journal of Supercritical Fluids, vol.47, no.3, pp.556-565, 2009.

[61] Fei Xia, Daode Hu, Heyang Jin, Yaping Zhao, Jiamiao Liang, "Preparation of lutein proliposomes by supercritical anti-solvent technique", Food Hydrocolloids, vol.26, no.2, pp.456-463, 2012.

[62] Fei Xia, Heyang Jin, Yaping Zhao, Xinqiu Guo, "Supercritical Antisolvent-based Technology for Preparation of Vitamin D3 Proliposome and Its Characteristics", Chinese Journal of Chemical Engineering, vol.19, no.6, pp.1039-1046, 2011.

[63] Sang-Do Yeo, Erdogan Kiran, "Formation of polymer particles with supercritical fluids: A review", The Journal of Supercritical Fluids, vol.34, no.3, pp.287-308, 2005. 